\title{
Impact of Tool Profile on Mechanical Properties of AZ31B Mg Alloy during FSW Using Optimized Parameters
}

Sevvel P

Associate Professor Department of Mechanical Engineering Magna College of Engineering, Magaral, Chennai - 600 055, Tamilnadu India

Jaiganesh V

Professor

Department of Mechanical Engineering S.A. Engineering College, Veeraraghavapuram, Thiruverkadu, Chennai- 600 077, Tamilnadu India
In this experimental investigation, an attempt was made to understand the influence of the tool profile on the mechanical properties of the joints fabricated during friction stir welding (FSW) of AZ31B Mg alloy flat plates. When the specimens prepared from the successfully fabricated joints were subjected to tensile tests as per prescribed International Standards it was observed that employing a taper cylindrical pin profiled tool resulted in sound quality lap joints with improved mechanical properties. Moreover, the use of other tool profiles namely straight cylindrical\&straightsquare could not produce defect free joints. Further, this investigation reveals us that the common FSW defects including low distortion, lack of cavity, tunnel defects etc are found to be completely eliminated while using taper cylindrical pin profiled tool.

Keywords: AZ31B Mg alloy, Friction stir welding, tool profile, mechanical properties.

\section{INTRODUCTION}

Magnesium ( $\mathrm{Mg}$ ) alloys, being one of the lightest structural materials, are nowadays widely replacing copper, aluminium and steel alloys in various and structural applications and automotive industries [1]. This is mainly due to their excellent properties including high strength in combination with a low density, greater thermal conductivity, sound castability and high machinability [2]. Welding defects \& solidification problems including hot cracking, porosity, partial melting zones, segregation of alloys etc are found to be present with the adoption of fusion welding techniques for $\mathrm{Mg}$ alloys [3].Hence, additional care should be taken while selecting the suitable welding process for fabricating parts composed of magnesium alloys.

Friction Stir Welding (FSW), an innovative type of solid state welding technique invented \& developed by The Welding Institute (TWI), seems to provide higher potential for joining magnesium alloys [4]. The main advantage of FSW process is that the welding takes place without melting the base metal, thereby eliminating the welding defects like porosity, cracks etc in the welded joints. Hence, this FSW is found to be more suitable for welding magnesium alloys when compared with the conventional resistance spot welding techniques [5].

\section{LITERATURE SURVEY}

Many experimental research works and investigations have been conducted and carried out on different

Received: May 2015, Accepted: October 2015

Correspondence to: P. Sevvel

Department of Mechanical Engineering, Magna College of Engineering, Magaral, Tamilnadu, India

E-mail: sevvel_ready@yahoo.co.in

doi:10.5937/fmet1601043J

(C) Faculty of Mechanical Engineering, Belgrade. Allrights reserved alloys of magnesium during their friction stir welding under various conditions and process parameters [610]. Woo et al. [6] made a detailed investigation on the AZ31B magnesium alloys and analyzed the spatial variations being produced in their chemical composition, hardness, microstructure, residual and texture stresses during their friction stir processing technique. They found that the friction stir processing produced negligible amount of variations in the chemical composition and hardness values of the AZ31B magnesium alloys in their weld zone and the size of the grains in the nugget zone have become finer when compared with that of the grains present in the base material. At the same time, they were able to find major variations in the yield strength and texture stresses in the friction stir processed zone and they developed a numerical relationship between the decrease in the yield strength values and stress variations present in the stir zone.

Venkateswarlu et al. [8] studied the impact of the tool designed with different shoulder diameters and their ratio of overlapping during the friction stir welding of AZ31 Mg alloy. Their work analyzed the effect of these parameters on the formability of the material, its mechanical properties including yield strength, percentage of elongation and tensile strength. They were able to produce joints containing fine refined grains with dynamic recrystallization capabilities in the joint area. They also proved that the use of the tool with $18 \mathrm{~mm}$ diameter shoulder \& 1.0 overlapping ratio was able to produce joints with improved formability values and fine homogeneous grain structure with grain size of $6.23 \mu \mathrm{m}$.

Dhanapal et al. [9] made an experimental attempt for arriving at a mathematical relationship using response surface technique to find out the rate of corrosion of the AZ61A magnesium alloy joints fabricated using friction stir welding. They made this investigation because of the 
reason that the magnesium alloys possess a high affinity for chemical agents which are oxidizing in nature and for oxygen. This inherent nature of the magnesium alloys with low levels of resistance towards corrosion plays an important role in hindering these alloys for use in a variety of industrial applications. The number of experiments \& conditions were decided using a three factorial composite design. They successfully developed a relationship which can be used to find out the rate of corrosion associated with the friction stir welded joints of AZ61A Mg alloys at a confidence level of $95 \%$.

Dietzel et al [10] utilized friction stir welding technique for joining AM50 magnesium alloy plates and made an investigation on the observations in the microstructures evolved during the process and the tensile strength of the resulting joints. They were successfully able to produce joints with $86.2 \%$ of the tensile strength and $94 \%$ of the yield strength of the base material respectively. They also revealed that there was a increase in the hardness value of the joints and the welded joints exhibited fractures with a quasi-cleavage feature unlike their parent metals with ductile fracture nature. Moreover, with the help of the optical microscopy images, they exhibited the presence of the fine refined grain structures in the weld zone which was very much smaller when compared with that of the grain size present in the base metal.

In this paper, AZ31B magnesium alloy was taken as the base metal and a detailed investigation was carried to experimentally measure the role of three different tool profiles namely straight square, straight cylindrical \& taper cylindrical tool pin profiles on various mechanical properties including tensile strength, yield strength and percentage of elongation during the friction stir welding of this magnesium alloy flat plates.

\section{EXPERIMENTAL WORK}

Magnesium alloy is taken as the parent material for this experimental investigation. The required thickness of $5 \mathrm{~mm}$ of the AZ31B magnesium alloy was obtained by machining the rolled plates to the required dimension. The rolled plates are then cut to the required length \& width (150 X $50 \mathrm{~mm}$ ) using power hacksaw followed by the milling process, and Figure 1 shows the photograph of the AZ31B Mg alloy specimens kept ready for joining process using the friction stir welding technique. The chemical compositions and mechanical properties of AZ31B wrought magnesium alloy are listed in Table 1.

The AZ31B Mg alloy flat plates were firmly secured in their position with the help of mechanical clamps and the tool is held rigidly in its position as shown in the Figure 2.

The Friction Stir Welding (FSW) of AZ31B magnesium alloys was performed using a semi automatic FSW machine with a table size of 810 X 400 $\mathrm{mm}$ and a spindle speed ranging from $20-2000 \mathrm{rpm}$ with a feed range of 0.25 to $500 \mathrm{~mm} / \mathrm{min}$. This machine has a motor power of $5 \mathrm{~kW}$ which can provide a 3 ton mechanical linear axial force in the vertical direction. Additionally, the machine has a $510 \mathrm{~mm}$ travel distance along the $\mathrm{X}$ axis, $400 \mathrm{~mm}$ along the $\mathrm{Y}$ axis and $400 \mathrm{~mm}$ with respect to the $Z$ axis.

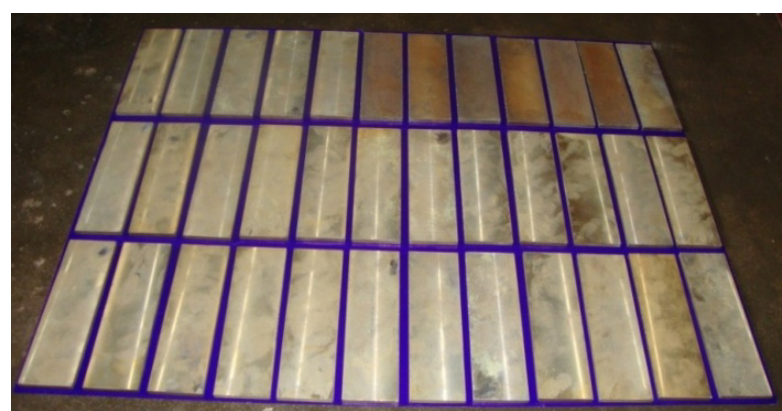

Figure 1: Photographic View of the AZ31B Magnesium Alloy flat plates of dimensions $150 \times 50 \times 5 \mathrm{~mm}$ before the friction stir welding process

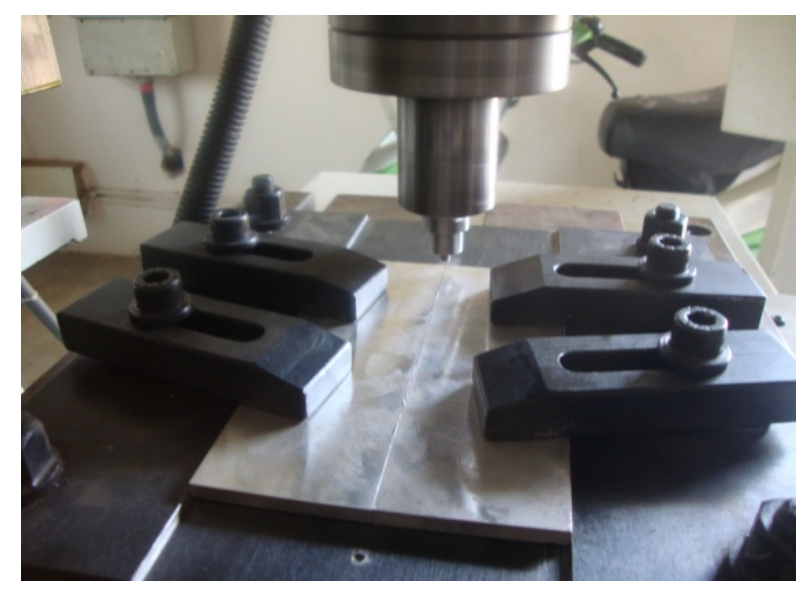

Figure 2: Initial Joint Configuration arrangement of AZ31B Mg Alloy flat plates in the Fixture along with the taper cylindrical pin profiled HSS tool

The Friction Stir Welding (FSW) of AZ31B magnesium alloys was performed using a semi automatic FSW machine with a table size of 810 X 400 $\mathrm{mm}$ and a spindle speed ranging from $20-2000 \mathrm{rpm}$ with a feed range of 0.25 to $500 \mathrm{~mm} / \mathrm{min}$. This machine has a motor power of $5 \mathrm{~kW}$ which can provide a 3 ton mechanical linear axial force in the vertical direction. Additionally, the machine has a $510 \mathrm{~mm}$ travel distance along the $\mathrm{X}$ axis, $400 \mathrm{~mm}$ along the $\mathrm{Y}$ axis and $400 \mathrm{~mm}$ with respect to the $Z$ axis.

\subsection{Tool material selection}

In FSW, the material of the tool is one of the most important key parameters in determining the quality of the welded joints being produced. The selection of the tool material is dependent on the material of the parent metal to be welded. Moreover, selection of suitable tool materials provides the opportunity of successfully carrying out the FSW process at varying combinations of rotational speeds and feed rates [11].

Non-consumable tool fabricated of M35 grade High Speed Steel (HSS) is taken as the tool material in this paper for FSW of AZ31B magnesium alloy flat plates.

The reason for choosing HSS as the tool material among the different variety of available tool materials like High Carbon High Chromium steel, Tool steel, carbide and carbon boron nitride is its ease of availability, high hot hardness, low cost, greater strengthand longer life time [12]. The heat treatment details and chemical composition of this HSS tool used in this paper are described in Table 2. 
Table 1. Chemical composition \& mechanical properties of AZ31B Mg alloy

\begin{tabular}{|c|c|c|c|c|c|c|c|c|c|c|c|}
\hline \multirow{2}{*}{ Alloy } & \multicolumn{5}{|c|}{ Composition wt \% } & \multicolumn{4}{c|}{ Mechanical Properties } \\
\cline { 2 - 12 } & $\mathrm{Al}$ & $\mathrm{Zn}$ & $\mathrm{Mn}$ & $\mathrm{Cu}$ & $\mathrm{Si}$ & $\mathrm{Fe}$ & $\mathrm{Ni}$ & $\mathrm{Mg}$ & $\begin{array}{c}\text { Tensile } \\
\text { strength }\end{array}$ & $\begin{array}{c}\text { Yield } \\
\text { Strength }\end{array}$ & $\begin{array}{c}\text { Elongation } \\
\text { percentage }\end{array}$ \\
\hline $\begin{array}{c}\text { AZ31B } \\
\text { Mg alloy }\end{array}$ & $2.5-3.5$ & $0.6-1.4$ & $0.2-1.0$ & 0.05 & 0.10 & 0.005 & 0.005 & balance & $\begin{array}{c}262 \\
\mathrm{MPa}\end{array}$ & $179 \mathrm{MPa}$ & $8 \%$ \\
\hline
\end{tabular}

Table 2: Chemical composition \& heat treatment details of M35 grade HSS Tool used in this paper

\begin{tabular}{|c|c|c|c|c|c|c|c|c|c|c|c|c|}
\hline \multirow{2}{*}{$\begin{array}{c}\text { Tool } \\
\text { Material }\end{array}$} & \multicolumn{9}{|c|}{ Composition wt \% } & \multicolumn{5}{c|}{ Heat Treatment Details } \\
\cline { 2 - 13 } & $\mathrm{C}$ & $\mathrm{Si}$ & $\mathrm{Mn}$ & $\mathrm{Cr}$ & $\mathrm{Mo}$ & $\mathrm{V}$ & $\mathrm{W}$ & $\mathrm{Co}$ & $\begin{array}{l}\text { Annealing } \\
\text { (Slow } \\
\text { cooling) }\end{array}$ & $\begin{array}{l}\text { Quenchent } \\
\text { (Hot Bath) }\end{array}$ & $\begin{array}{l}\text { Tempering } \\
\text { (Air cooling) }\end{array}$ & $\begin{array}{l}\text { Quenched } \\
\&(\mathrm{hrc}) \\
\text { tempered }\end{array}$ \\
\hline $\begin{array}{c}\text { M35 grade } \\
\text { HSS }\end{array}$ & 0.92 & 0.35 & 0.3 & 4.1 & 5 & 1.9 & 6.4 & 4.8 & $800-840$ & oil & $550-570$ & 61 \\
\hline
\end{tabular}

\section{Design of tool pin profile}

The tool pin profile and its geometry are found to play a significant role in determining the generation of heat and plastic flow during FSW. Moreover, the uniformity of the welded joint produced and the soundness of the good quality of the produced weld are directly dependant on the tool pin profiles and their geometry [13].

The shoulder generally performs the function of generating larger amount of heat and it alsoperforms the function of preventing the plasticized material from escaping the surface of the work piece. The pin profile has been found to have a major input on the flow of materials in the stir zone during the FSW process [14].

The three different tool pin geometries used in this paper are straight cylindrical, straight square and taper cylindrical. Figure 3 shows the photographic view of these three different pin profiles.

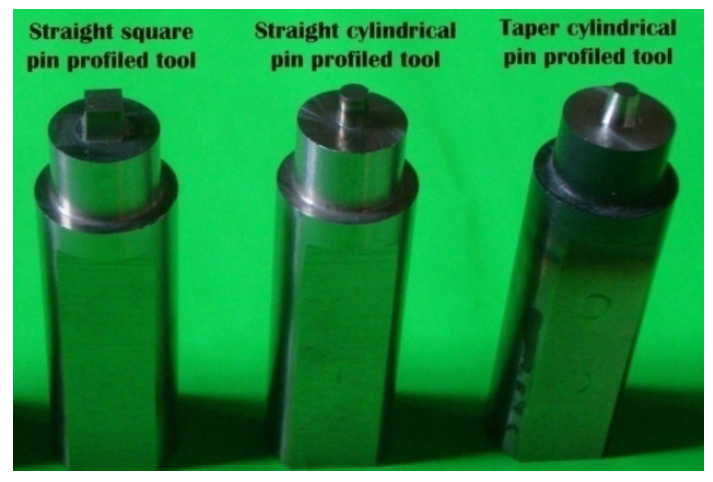

Figure 3: Photographic view of HSS tools with different pin profiles

The specifications and dimensions of the three different tool pin profiles used in this investigation are summarized in Table 3.

All the three tool different pin profile geometries are obtained with the help of a CNC Turning centre and optical profile type of grinding machine. The tools manufactured using these machines are then subjected to various suitable hardening processes to obtain a hardness of $60-62$ HRC. All the three tools with different pin profile geometries have an outside shoulder diameter of $20 \mathrm{~mm}$ with a length of $50 \mathrm{~mm}$ and an inner shoulder diameter of $15 \mathrm{~mm}$ with a length of $10 \mathrm{~mm}$. All the tools have a $\mathrm{D} / \mathrm{d}$ ratio of 3 .
Table 3: Specifications and dimensions of the different tool pin profiles used in this paper

\begin{tabular}{|c|c|c|c|c|c|}
\hline \multirow[b]{2}{*}{$\begin{array}{l}\text { Shape of } \\
\text { the tool pin } \\
\text { profile }\end{array}$} & \multicolumn{5}{|c|}{ Tool specifications \& dimensions } \\
\hline & \begin{tabular}{|c|} 
Inner \\
Shoulder \\
Diameter \\
D (mm) \\
\end{tabular} & $\begin{array}{c}\text { Pin } \\
\text { Length } \\
\text { L, } \\
(\mathrm{mm})\end{array}$ & $\begin{array}{l}\text { Major Pin } \\
\text { Diameter } \\
(\mathrm{mm})\end{array}$ & $\begin{array}{c}\text { Minor } \\
\text { Pin } \\
\text { Diameter } \\
\mathrm{d},(\mathrm{mm}) \\
\end{array}$ & $\begin{array}{c}\mathrm{D} / \mathrm{d} \\
\text { ratio } \\
\text { of the } \\
\text { tool }\end{array}$ \\
\hline $\begin{array}{l}\text { Straight } \\
\text { Cylindrical }\end{array}$ & 12 & 4.75 & 4 & 4 & 3 \\
\hline $\begin{array}{l}\text { Straight } \\
\text { square }\end{array}$ & 12 & 4.75 & 4 & 4 & 3 \\
\hline $\begin{array}{l}\text { Taper } \\
\text { Cylindrical }\end{array}$ & 12 & 4.75 & 7 & 4 & 3 \\
\hline
\end{tabular}

\section{Optimized welding parameters and fabrication}

Since this paper principally investigates the impact of the tool profile on the mechanical properties of the friction stir welded AZ31B Mg alloy flat plates, the other welding parameters, such as tool rotational speed, welding speed and the axial force were set to the already proven optimized values during the friction stir welding of various grades of alloys like aluminium \& copper [15-17]. Friction stir welding was successfully carried out on a number of AZ31B Magnesium alloy flat plates using the three different tool pin profiles at the optimized process parameters which are listed in table 4 below.

Table 4: Optimized process parameters used during FSW of AZ31B Mg alloy flat plates in this investigation

\begin{tabular}{|l|c|}
\hline Process parameters & $\begin{array}{c}\text { Optimized values of the } \\
\text { process parameters }\end{array}$ \\
\hline Tool rotational speed $(\mathrm{rpm})$ & 750 \\
\hline Feed rate $(\mathrm{mm} / \mathrm{min})$ & 0.5 \\
\hline Axial force $(\mathrm{kN})$ & 3 \\
\hline
\end{tabular}

Friction stir welding is carried out in such a way that the welding direction is normal to the rolling direction of the specimen plates. Further, it is ensured that necessary care was taken in order to avoid distortion during the joining process and the joints were fabricated using the single pass welding technique. 


\section{RESULTS AND DISCUSSIONS}

\section{Appearance of joints}

The photographic view of sample of the joints successfully fabricated during the friction stir welding of the AZ31B magnesium alloy flat platesusing the M35 grade HSS tool with three different pin profile geometries namely straight cylindrical, straight square and taper cylindrical under optimized process parameters are illustrated in Figure 4.

\section{Macrostructure of the FSW joints}

The top surface of the majority of the welded joints seemed to be free from visible defects. However, the cross sections of some of the welded specimens are found to be present with tunnel defects in the various sections of the welded zone. These defects were observed when the welded specimens were analysed under the low magnification (10X) using the optical microscope and the macrostructure of the fabricated
AZ31B magnesium specimens using three different pin profiles are clearly displayed in the Figure 5.

Of the various joints fabricated during this process, the joint fabricated using a taper cylindrical pin profiled tool was found to be free from welding defects and had been observed as a defect free joint, as shown in the Figure 5c. This may be one of the reasons for obtaining a higher value of tensile strength with the same joint.

The joints fabricated with the straight cylindrical were observed to be present with minimum amount of tunnel defect. At the same time, the use of straight square pin profiled tool was found to produce joints in which the larger tunnel defects were present. From the macroscopic observations of the welded specimens shown in Figure 5, it had been experimentally found that the use of the taper cylindrical pin profiled tool under optimized parameters of 750 rotational speed, $0.5 \mathrm{~mm} / \mathrm{min}$ feed rate and $3 \mathrm{kN}$ axial force values was found to produce sound and better weld quality defect free joints with negligible defects and even a completely defect free joint when compared with other two pin profiled tools.

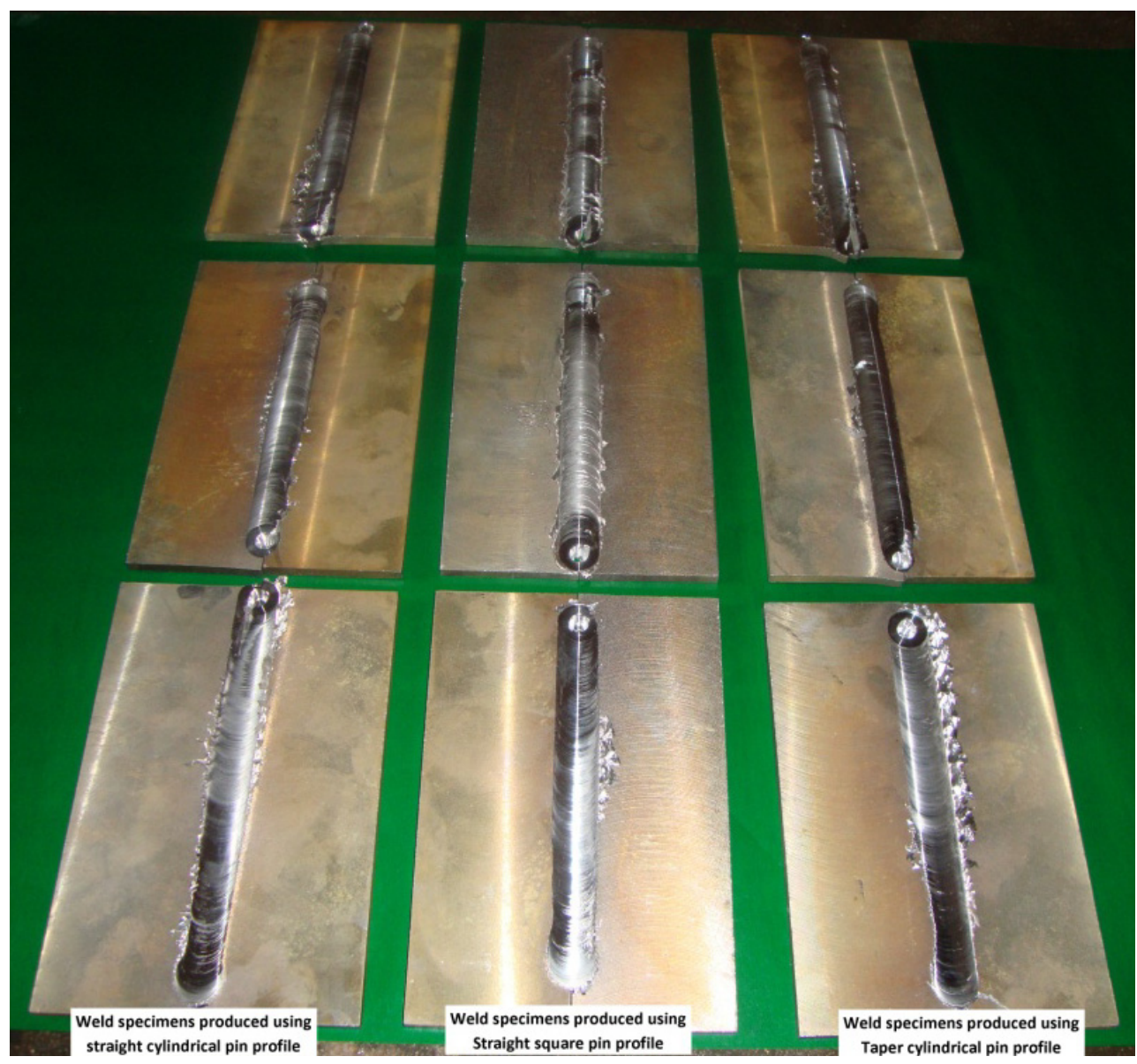

Figure 4: Photographic View of the sample of the AZ31B magnesium alloy joints successfully fabricated by the friction stir welding process using three different tool pin profiles at optimized process parameters

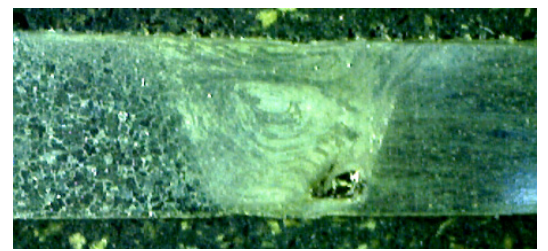

(a)

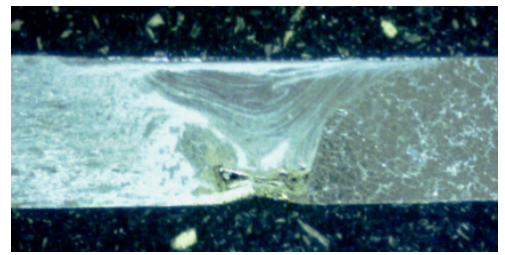

(b)

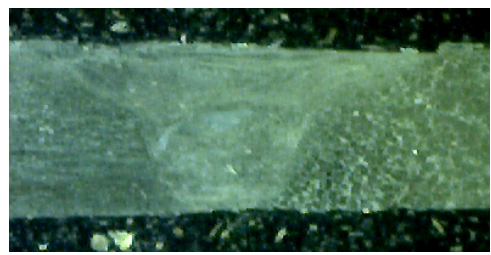

(c)

Figure 5: Photographic Image of the macrostructure of the fabricated AZ31B magnesium specimens by three different pin profiles namely (a) Straight square (b) straight cylindrical (c) taper cylindrical under optimized process parameters 


\section{Mechanical properties}

In order to investigate and characterize the mechanical properties of the friction stir welded specimens using three different tool pin profiles, a series of tensile shear tests were conducted as per the International standards. Procedures prescribed by the American Society for Testing of Materials (ASTM: B557M-10) standard guidelines were adopted during the preparation of the specimens for carrying out the tensile tests. Photograph of the tensile test specimens prepared by the above mentioned standard are illustrated in Figure 6.

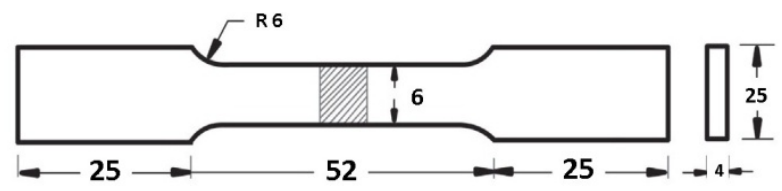

Figure 6: Tensile specimen prepared as per ASTM: B557M-10 standard guidelines

The lengths of the tensile test specimens were cut along the processed direction. The shape of the tensile test specimens were obtained by slicing the single pass friction stir welded pieces using power hacksaw machine. The photographic view of the prepared tensile specimens as per the above mentioned processes can be seen in the Figure 7 and these tensile test specimens were used to evaluate the tensile strength, yield strength and \% elongation of the friction stir welded AZ31B Mg alloy plates.

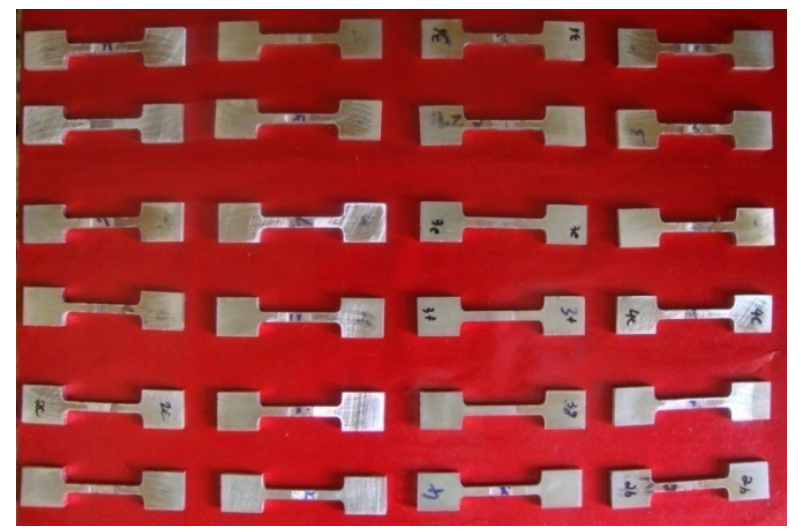

Figure 7: Photographic View of the tensile test specimen prepared as per the ASTM: B557M-10 standard guidelines before tensile testing

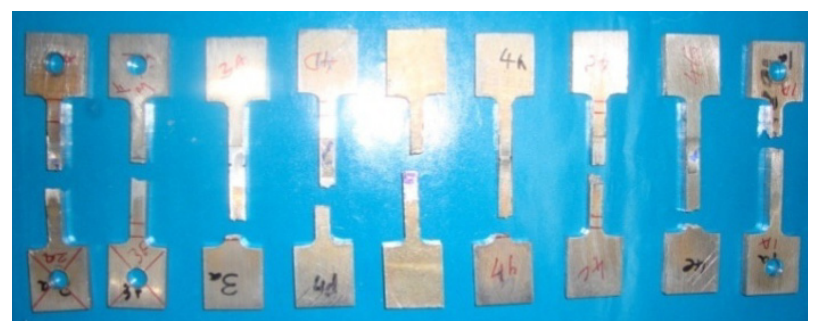

Figure 8: Photographic View of the sample of the tensile test specimen after tensile testing

After machining, the prepared tensile specimens were inspected and loaded at the rate of $1 \mathrm{kN} / \mathrm{min}$ as per the ASTM guidelines and Figure 8 shows the photographic view of the tensile test specimens after the completion of the tensile testing using the universal testing machine.
Each of two to three specimens produced using three different pin profiles were subjected to tensile testing and the stress strain graph generated during this tensile testing for the specimen welded using different pin profiles are shown in the Figure 9. As depicted in the Figure 9 (c), of the various welded joints, the joints fabricated using taper cylindrical pin profile was found to yield better tensile properties. The ultimate tensile strength exhibited by this joint specimen is $168 \mathrm{MPa}$ which is approximately $64.12 \%$ of the tensile strength of the AZ31B magnesium alloy (262 MPa). Moreover, the yield strength exhibited by this joint is $98 \mathrm{MPa}$ which is approximately $54.7 \%$ than that of the parent metal $(179 \mathrm{MPa})$. The related percentage of elongation for this joint is $5.45 \%$.
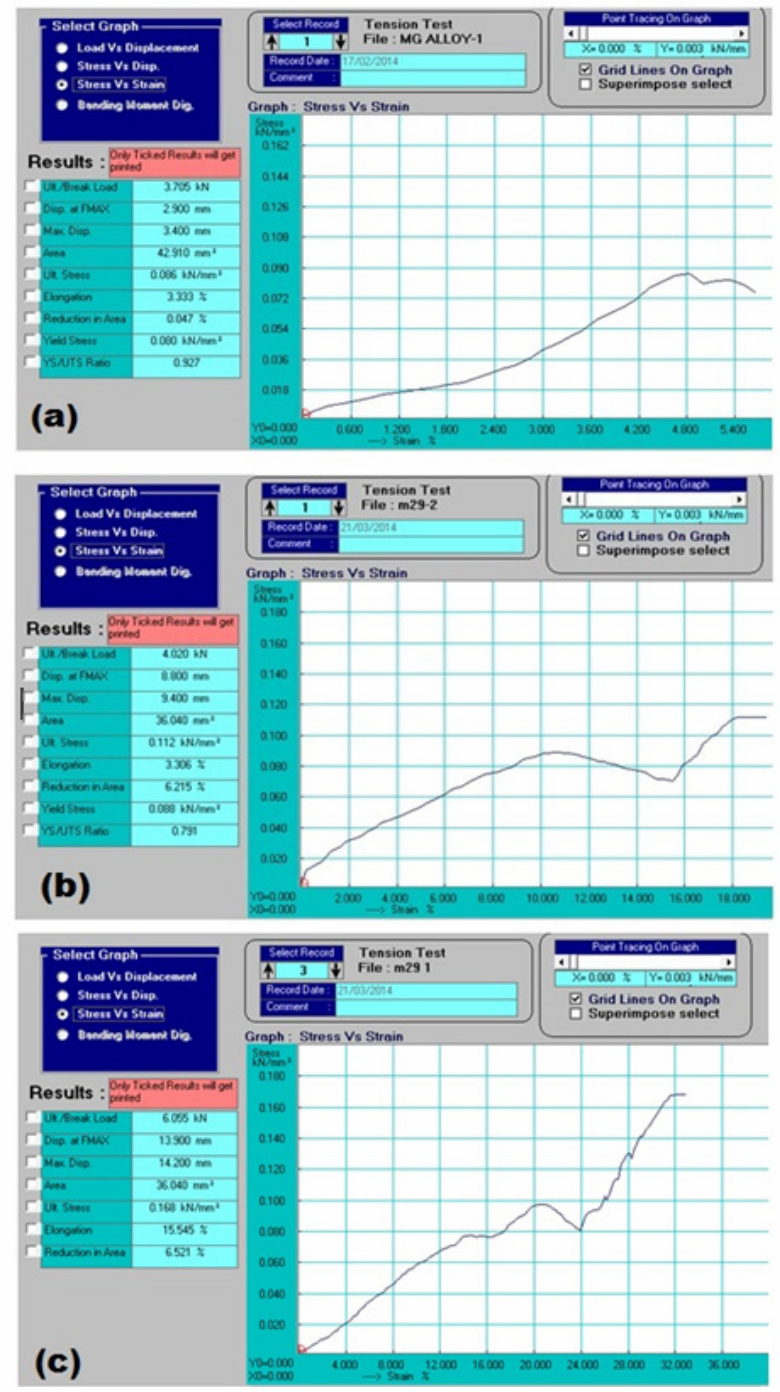

Figure 9: Stress strain graph generated during the tensile testing for the specimen welded using (a) Straight square (b) straight cylindrical (c) taper cylindrical pin profiles

\section{CONCLUSIONS \& FUTURE SCOPE}

In this paper, a detailed investigation had been carried out to find out the changes being produced in the macro structural characterization and mechanical properties of the AZ31B Mg alloy by using three different tool pin profiles at the optimized process parameter values including tool rotational speed of 750 $\mathrm{rpm}, 0.5 \mathrm{~mm} / \mathrm{min}$ feed rate and axial force of $3 \mathrm{kN}$ 
during the FSW. The following conclusions have been experimentally derived:

1) It had been experimentally proved that for joining of AZ31B Mg alloy flat plates of $5 \mathrm{~mm}$ thickness using the FSW technique at the optimized process parameters, taper cylindrical pin profiled is preferable compared with the other tool pin profiles and this taper cylindrical pin profiled tool was found to exhibit improved \& better mechanical properties when compared with the other two pin profiles under FSW parameters of optimized values.

2) The tensile strength value produced using the taper cylindrical pin profile is about $64.12 \%$ of the strength of the base metal. Likewise, the related yield strength value is nearly $54.5 \%$ of its base metal and the percentage of elongation being $5.45 \%$.

Additionally, the paper also provides a wide scope for carrying out future experimental and numerical investigations on enhancing and improving the micro structural characterization of the AZ31B Mg alloy joints using the taper cylindrical pin profiled tool during the FSW process.

\section{ACKNOWLEDGMENT}

The authors gratefully thank the Management and Mechanical Engg Dept., S.A Engineering College, Chennai, India for providing the welding equipment facilities. The authors wish to express thanks to All India Council for Technical Education (AICTE) Govt. of INDIA, funded project (Grant No. 8023/RID/RPS/ 037/2011-12) for sponsoring FSW machine.

\section{REFERENCES}

[1] Cao, X. and Jahazi M.: Effect of tool rotational speed and probe length on lap joint quality of a friction stir welded Mg alloy, Mater Des Vol. 32, pp. $01-11$, 2011.

[2] Mordike, B.L. and Ebert, T.: Magnesium: properties - applications - potential, Materials Science Engineering A, pp. 37 - 45, 2000.

[3] Avedeelan, M.M. and Baker,H.: Magnesium and Magnesium Alloys, ASM Special Handbook, ASM International, pp. 106 - 118, 1999.

[4] Sevvel, P. and Jaiganesh, V.: An detailed examination on the future prospects of friction stir welding - a green technology, Proceedings of the International Conference on Advances In Industrial Engineering Applications - ICAIEA 2014, January $06-08$, pp. 62 - 63, 2014.

[5] Nandan, R., DebRoy, T. and Bhadeshia,H.K.D.H.: Recent trends in friction stir welding process, weldment structure and properties, Prog. Mater. Sci., pp. 980-1023, 2008.

[6] Woo, W., Choo, H., Prime, M.B., Feng, Z. and Clausen,B.: Microstructure, texture and residual stress in a friction-stir-processed AZ31B magnesium alloy, Acta Mater., Vol. 56, No. 8, pp. 1701-1711, May 2008.
[7] Ramesh Babu,S., Senthil Kumar,V. S., Karunamoorthy, L. and Madhusudhan Reddy,G.: Investigation on the effect of friction stir processing on the superplastic forming of AZ31B alloy, Mater. Des., Vol. 53, pp. 338-348, Jan. 2014.

[8] Zhao,Y.H., Lin,S.B., Qu,F. X. and Wu,L.: Influence of pin geometry on materialflow in friction stir welding process, Materials Science and Technology, vol. 22(1), pp. 45-50, 2006.

[9] Dhanapal,A., Boopathy,S.R. and Balasubramanian, V.: Developing an empirical relationship to predict the corrosion rate of friction stir welded AZ61A magnesium alloy under salt fog environment, Mater. Des., Vol. 32, no. 10, pp. 5066-5072, Dec. 2011

[10] Zeng,R., Dietzel,W., Zettler,R., Chen,J. and Kainer,K. U.: Microstructure evolution and tensile properties of friction-stir-welded AM50 magnesium alloy, Trans. Nonferrous Met. Soc. China, Vol. 18, pp. s76-s80, Dec. 2008.

[11] Sevvel, P. and Jaiganesh,V.: A detailed investigation on the role of different Tool Geometry in Friction Stir Welding of various Metals \& their Alloys, Proceedings of the International Colloquium on Materials, Manufacturing \& Metrology - ICMMM, August 89, Pp 103 - 107, 2014.

[12] Ganesa Balamurugan, K. and Mahadevan,K.: Investigation on the changes effected by tool profile on mechanical and tribological properties of friction stir processed AZ31B magnesium alloy, J. Manuf. Process., Vol. 15, No. 4, pp. 659-665, 2013.

[13] Tozaki,Y., Uematsu,Y. and Tokaji,K.: A newly developed tool without probe for friction stir spot welding and its performance, J. Mater. Process. Technol., Vol. 210, pp.844-851, 2010.

[14] Sevvel, P. and Jaiganesh,V.: Experimental Investigation on the impact of the Tool Material \& geometry in joining of Al 63400 Alloy using Friction Stir Welding Process, Applied Mechanics and Materials Vol. 592-594, pp. 312315, 2014.

[15] Lombord,H., Hattingh,D.G., Steuwer,A. and James,M.N.: Optimizing FSW process parameters to minimize defects and maximizing fatigue life in 5083 - H321 aluminium alloy, J. Eng Fract Mech, pp. $341-354,2008$.

[16]Sevvel, P. and Jaiganesh,V.: "Improving the mechanical properties of friction stir welded AZ31B magnesium alloy flat plates through axial force investigation", vol. 591, pp. 11-14, 2014.

[17] Sun, Y.F. and Fujii,H.: Investigation of the welding parameter dependent microstructure and mechanical properties of friction stir welded pure copper, Mater. Sci. Eng. A, Vol. 527, no. 26, pp. 6879-6886, 2010. 
УТИЦАЈ ПРОФИЛА АЛАТА НА МЕХАНИЧКЕ КАРАКТЕРИСТИКЕ МАГНЕЗИЈУМОВЕ ЛЕГУРЕ АZЗ1В КОД ЗАВАРИВАЊА ТРЕЊЕМ СА МЕШАҢЕМ ПРИМЕНОМ ОПТИМИЗИРАНИХ ПАРАМЕТАРА

\section{Sevvel P., Jaiganesh V.}

Овим експерименталним истраживањем покушали смо да разумемо колико профил алата утиче на механичке карактеристике склопова од равних лимова произведених од магнезијумове легуре AZ31B и добијених заваривањем трењем са мешањем. Када су узорци успешно припремљени од произведених склопова изложени су испитивању затезањем према међународним стандардима, уочили смо да се коришћењем зашиљених коничних чивија добија квалитетнији лим са побољшаним механичким својствима. Осим тога, применом других профила алата, тј. чивија са коничним и квадратним профилом, добили смо спојеве са дефектима. Ово истраживање је показало да уобичајени дефекти код заваривања трењем са мешањем, као што је мала дисторзија, одсуство шупљина у потпуности се отклањају коришћењем алата са профилом зашиљене коничне чивије. 